\title{
Regulatory Effects of Glucose on the Catalytic Activity and Cellular Content of Glucokinase in the Pancreatic $\beta$ Cell Study Using Cultured Rat Islets
}

\author{
Chuan Chen, Hitoshi Hosokawa, Lisa M. Bumbalo, and Jack L. Leahy \\ Division of Endocrinology, Diabetes, Metabolism, and Molecular Medicine, New England Medical Center and Tufts University School \\ of Medicine, Boston, Massachusetts 02111
}

\begin{abstract}
Glucose regulates the cellular content of glucokinase in the pancreatic $\beta$ cell by altering the level of the enzyme. We investigated the existence of a second regulatory pathway, an alteration in the catalytic activity, by comparing $V_{\max }$ and protein levels of glucokinase in rat islets cultured under high glucose conditions $(16.7 \mathrm{mM})$ for 6,14 , and $24 \mathrm{~h}$. The $V_{\max }$ was increased by glucose at all time points. In contrast, glucokinase protein levels on Western blots were unchanged from the control value at $6 \mathrm{~h}$ but increased $40 \%$ at the later time points $(P<0.0002)$. Further evidence for a dual regulatory system was obtained with a reversal protocol. After a 6-h incubation at high glucose, an additional 3-h incubation at $5.5 \mathrm{mM}$ glucose restored glucokinase $V_{\max }$ to normal, but failed to change the $V_{\max }$ after a 24-h incubation at high glucose. Finally, $10 \mu \mathrm{M}$ cycloheximide partially prevented the increase in glucokinase $V_{\max }$ induced by $24 \mathrm{~h}$ of high glucose, but had no effect at $6 \mathrm{~h}$, suggesting the early increase in enzymatic activity did not require protein synthesis.

In summary, glucose regulates both the catalytic activity and cellular content of glucokinase in the $\beta$ cell. Glucoseinduced increases in glucokinase activity are an important element of the $\beta$ cell adaptive response to hyperglycemia. (J. Clin. Invest. 1994. 94:1616-1620.) Key words: islets of Langerhans - insulin secretion - glucose phosphorylation • hexokinase $\bullet$ immunoblot
\end{abstract}

\section{Introduction}

In hepatocytes and pancreatic $\beta$ cells, the high $K_{\mathrm{m}}$ glucose phosphorylation enzyme glucokinase is the rate-limiting step for glucose metabolism, and a key site of regulation for glucoseinduced insulin secretion and hepatic glucose production $(1$, 2 ). The recent discovery that glucokinase gene mutations account for many of the cases of MODY (maturity-onset diabetes of youth) hás pointed out the pivotal role played by this enzyme in glucose homeostasis $(3,4)$. Different isoforms with separate regulatory controls occur in the liver and $\beta$ cell $(5,6)$. Interest

Address correspondence to Dr. Jack Leahy, New England Medical Center \#268, 750 Washington Street, Boston, MA 02111. 1994.

Received for publication 1 April 1994 and in revised form 30 June

J. Clin. Invest.

(c) The American Society for Clinical Investigation, Inc.

0021-9738/94/10/1616/05 \$2.00

Volume 94, October 1994, 1616-1620 has focused primarily on glucose as a regulatory factor of the $\beta$ cell isoform. Culturing rat islets in high glucose for $24 \mathrm{~h}$ causes the cellular content of this enzyme to increase without changing the mRNA level (7). Culture in low glucose has the opposite effect (7). This posttranscriptional regulation of the synthesis and/or degradation of glucokinase by glucose is to date the only known mode of regulation for the $\beta$ cell isoform.

We recently postulated that a second type of regulation occurs at the level of the catalytic activity of the enzyme. This hypothesis was based on our findings in two hyperinsulinemic rat models of increased activity of islet glucokinase without any change in the level of its protein measured by Western blot ( 8 , 9 ). The present study was designed to test if glucose regulates the activity of this enzyme independent of changes in its cellular content by comparing glucokinase $V_{\max }$ and protein levels in rat islets cultured at high concentrations of glucose for 6,14 , or $24 \mathrm{~h}$. A dual regulatory system was confirmed, with glucose increasing both the catalytic activity and cellular content of glucokinase over different time courses and with different susceptibilities to reversal.

\section{Methods}

Isolation and culture of islets. Male Sprague-Dawley rats (150-200 g) were anesthetized with pentobarbital sodium $(100 \mathrm{mg} / \mathrm{kg}$ i.p.). Islets were isolated using an adaption of the method of Gotoh et al. (10): pancreatic duct infiltration with collagenase, Histopaque gradient separation (Sigma Chemical Co., St. Louis, MO), and hand picking. Islets were cultured in RPMI 1640 medium supplemented with $2 \mathrm{mM}$ glutamine, $10 \%$ newborn calf serum, $100 \mathrm{U} / \mathrm{ml}$ penicillin, and $0.1 \mathrm{mg} / \mathrm{ml}$ streptomycin (all from Gibco Laboratories, Grand Island, NY) at $37^{\circ} \mathrm{C}$ in humidified air $/ 5 \% \mathrm{CO}_{2}$.

Protocols. (a) $18 \mathrm{~h}$ of $5.5 \mathrm{mM}$ glucose followed by $16.7 \mathrm{mM}$ glucose $\times 6 \mathrm{~h} ; 16.7 \mathrm{mM}$ glucose $\times 24 \mathrm{~h} ; 5.5 \mathrm{mM}$ glucose $\times 24 \mathrm{~h}$. (b) $4 \mathrm{~h}$ of $5.5 \mathrm{mM}$ glucose followed by $16.7 \mathrm{mM}$ glucose $\times 14 \mathrm{~h} ; 5.5 \mathrm{mM}$ glucose $\times 18 \mathrm{~h}$. (c) Groups of protocol $a$ followed by an additional 3 $\mathrm{h}$ at $5.5 \mathrm{mM}$ glucose. $(d) 18 \mathrm{~h}$ of $5.5 \mathrm{mM}$ glucose followed by 16.7 $\mathrm{mM}$ glucose $\times 6 \mathrm{~h}$ with or without $10 \mu \mathrm{M}$ cycloheximide (Sigma Chemical Co.); $16.7 \mathrm{mM}$ glucose $\times 24 \mathrm{~h}$ with or without $10 \mu \mathrm{M}$ cycloheximide; $5.5 \mathrm{mM}$ glucose $\times 24 \mathrm{~h}$.

Insulin secretion. Islets were washed three times in KRB, $10 \mathrm{mM}$ Hepes, $2.8 \mathrm{mM}$ glucose, 0.5\% BSA fraction V (Sigma Chemical Co.), and preincubated in the same buffer for $90 \mathrm{~min}$ at $37^{\circ} \mathrm{C}$. Triplicate batches of 10 islets were transferred to glass vials containing $1 \mathrm{ml}$ KRB $+2.8-27.7 \mathrm{mM}$ glucose, and incubated $60 \mathrm{~min}$ in a $37^{\circ} \mathrm{C}$ shaking water bath. The medium was separated from the islets by gentle centrifugation $\left(500-750 \mathrm{rpm} 5 \mathrm{~min}\right.$ at $10^{\circ} \mathrm{C}$ ) and stored at $-20^{\circ} \mathrm{C}$ pending measurement of insulin with an RIA that used charcoal separation (11) and rat insulin standards (Eli Lilly and Company, Indianapolis, IN). The three replicates at each glucose concentration were combined to give a single data point.

Glucokinase enzymatic activity. Islets were preincubated $90 \mathrm{~min}$ at $2.8 \mathrm{mM}$ glucose, homogenized, and centrifuged $10 \mathrm{~min}$ at $12,000 \mathrm{~g}$ to remove mitochondrial-bound hexokinase (12). DNA content was 


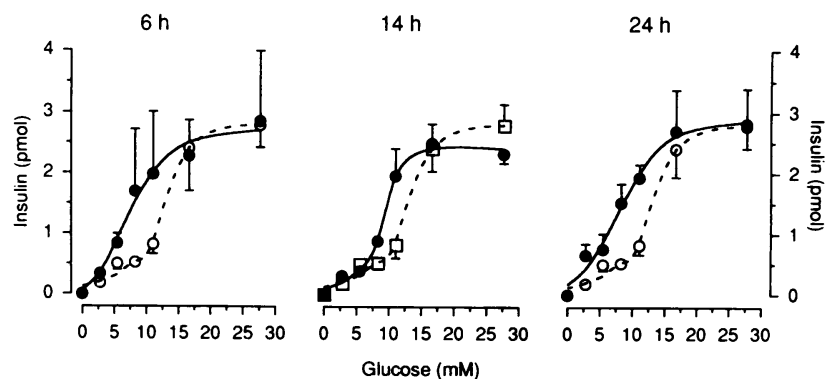

Figure 1. Glucose/insulin secretion dose response curves in cultured rat islets. (Left panel) Islets cultured $6 \mathrm{~h}$ at $16.7 \mathrm{mM}$ glucose preceded by $18 \mathrm{~h}$ at $5.5 \mathrm{mM}$ glucose $(\bullet-\cdots n=3)$ and $24 \mathrm{~h}$ at $5.5 \mathrm{mM}$ glucose $(\mathrm{O}-\mathrm{O} n=3)$. (Middle panel) Islets cultured $14 \mathrm{~h}$ at 16.7 $\mathrm{mM}$ glucose preceded by $4 \mathrm{~h}$ at $5.5 \mathrm{mM}$ glucose $(\bullet-\cdots n=3)$ and $18 \mathrm{~h}$ at $5.5 \mathrm{mM}$ glucose ( $\square-\square \square, n=3$ ). (Right panel) islets cultured $24 \mathrm{~h}$ at $16.7 \mathrm{mM}$ glucose $(\bullet-\cdots n=3)$ and $24 \mathrm{~h}$ at $5.5 \mathrm{mM}$ glucose $(\bigcirc-— \circ n=3)$. 10 islets per vial were incubated $60 \mathrm{~min}$ at the glucose concentrations shown.

measured in $10 \mu \mathrm{l}$ aliquots $\times 3(13)$. Glucose phosphorylation was measured as the conversion of $\mathrm{NAD}^{+}$to $\mathrm{NADH}$ by exogenous glucose6-phosphate dehydrogenase $(7,14)$. Extract $(5 \mu \mathrm{l})$ was added to 100 $\mu \mathrm{l}$ of reaction buffer $(50 \mathrm{mM}$ Hepes $/ \mathrm{HCl} \mathrm{pH} 7.60,100 \mathrm{mM} \mathrm{KCl}, 7.4$ $\mathrm{mM} \mathrm{MgCl}_{2}, 0.05 \%$ BSA, $5 \mathrm{mM}$ ATP, $0.5 \mathrm{mM} \mathrm{NAD}^{+}, 15 \mathrm{mM} \beta-$ mercaptoethanol, $0.7 \mathrm{U} / \mathrm{ml}$ glucose-6-phosphate dehydrogenase from Leuconostoc mesenteroides (Boehringer Mannheim, Indianapolis, IN), $0.03-100 \mathrm{mM}$ glucose), and incubated $90 \mathrm{~min}$ at $30^{\circ} \mathrm{C}$. The reaction was stopped with $1 \mathrm{ml} 500 \mathrm{mM} \mathrm{NaHCO} 3 \mathrm{pH} 9.4$. Triplicate samples were measured per glucose concentration (excitation $350 \mathrm{~nm} /$ emission $460 / \mathrm{nm})$, and the mean value used as a single observation. The standard curve used glucose-6-phosphate standards $(0.3-3.0 \mathrm{nmol})$ in reaction buffer that contained $100 \mathrm{mM}$ glucose. Glucokinase and hexokinase $V_{\max }$ and $K_{\mathrm{m}}$ were calculated by linear regression from an EadieScatchard plot $(v /[s]$ vs $v)$ after extrapolating the data to $37^{\circ} \mathrm{C}$ assuming a $Q_{10}$ of $2(15)$ followed by 10 cycles of the method of Spears et al. (16).

Glucokinase Western blot. 300-500 islets were lysed in 5\% SDS, $80 \mathrm{mM}$ Tris $/ \mathrm{HCl} \mathrm{pH} 6.8,1 \mathrm{mM}$ phenylmethylsulfonyl fluoride, $10 \mu \mathrm{g}$ DNAase, $0.2 \mathrm{mM} N$-ethylmaleimide, and $5 \mathrm{mM}$ EDTA. Protein content was measured by the BCA assay (Pierce, Rockford, IL) with BSA as standard. 20- $\mu$ g protein aliquots were resolved by electrophoresis on a $0.75-\mathrm{mm} 10 \%$ polyacrylamide gel containing SDS, and were electroblotted onto nitrocellulose (Schleicher \& Schuell Inc., Keene, NH) (17). After blocking overnight at $4^{\circ} \mathrm{C}$ in $5 \%$ nonfat dry milk $/ 0.01 \%$ Tween 20 in $20 \mathrm{mM}$ Tris/ $\mathrm{HCl} \mathrm{pH} \mathrm{7.4,} \mathrm{filters} \mathrm{were} \mathrm{incubated} \mathrm{with} \mathrm{a} \mathrm{polyclonal}$ sheep antiserum (1:500 dilution for $3 \mathrm{~h}$ at room temperature) raised against an Escherichia coli-derived B1 isoform of rat glucokinase (gift from Dr. Mark Magnuson, Vanderbilt University, Nashville, TN), then rabbit anti-sheep IgG antiserum (Sigma Chemical Co.) at 1:1500 dilution for $1 \mathrm{~h}$. Bound antibody was detected by ${ }^{125} \mathrm{I}$-conjugated protein $\mathrm{A}$ (ICN, Costa Mesa, CA), and quantified by densitometry using IMAGE 1.4 software (National Institutes of Health, Bethesda, MD).

Data presentation and statistical methods. Data are expressed as mean \pm SEM with the reported $n$ always being the number of experiments. The high glucose culture times were $6 \mathrm{~h}$ (protocol $a$ ), $14 \mathrm{~h}$ (protocol $b$ ), and $24 \mathrm{~h}$ (protocol $a$ ). Statistical comparisons were made with the islets incubated at $5.5 \mathrm{mM}$ glucose from that protocol ("timematched controls"') using one-way ANOVA. The one-way Student's $t$ test was used for the Western blot results by assigning a densitometry reading of $100 \%$ to the $5.5-\mathrm{mM}$ glucose islets on each gel.

\section{Results}

Insulin secretion. Glucose/insulin dose response curves were constructed over a glucose range of $2.8-27.7 \mathrm{mM}$ (Fig. 1). As

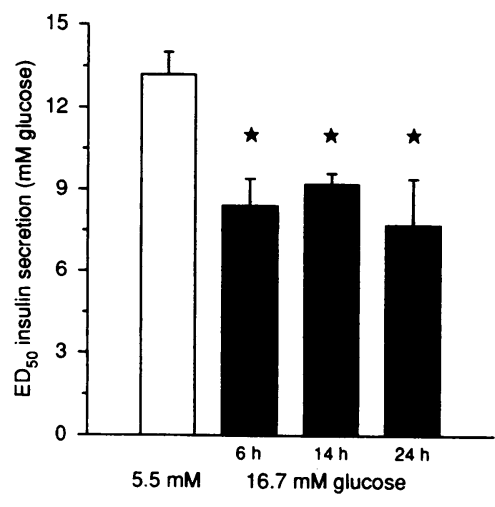

Figure 2. The $\mathrm{ED}_{50}$ for glucose-induced insulin secretion in islets cultured for 6,14 , or $24 \mathrm{~h}$ at $16.7 \mathrm{mM}$ glucose. The half-maximal glucose concentration $\left(\mathrm{ED}_{50}\right)$ was calculated from the curves in Fig. 1. $\star$, statistically significant result vs the $5.5-\mathrm{mM}$ glucose islets ( $P$ values are in the text).

expected, the curves for the control islets (cultured at $5.5 \mathrm{mM}$ glucose) from protocols $a$ and $b$ were superimposable with halfmaximal glucose concentrations $\left(\mathrm{ED}_{50}\right)$ of $12.5 \pm 0.3 \mathrm{mM}$ in the 18 -h controls and $13.2 \pm 0.8 \mathrm{mM}$ in the 24 -h controls. After 6 $\mathrm{h}$ of high glucose, the $\mathrm{ED}_{50}$ for glucose was $8.4 \pm 1.0 \mathrm{mM}$ ( $P$ $<0.02$ ) with no change in the maximal response. Extending the time to $14 \mathrm{~h}$ and then $24 \mathrm{~h}$ caused no additional left shift of the curve (Fig. 2). The $\mathrm{ED}_{50}$ for glucose at $14 \mathrm{~h}$ was $9.2 \pm 0.4$ $\mathrm{mM}(P<0.004$ vs time-matched controls $)$ and $7.7 \pm 1.7 \mathrm{mM}$ at $24 \mathrm{~h}(P<0.043$ vs time-matched controls $)$.

Glucokinase enzymatic activity. The $V_{\max }$ and $K_{\mathrm{m}}$ values for glucokinase and hexokinase are listed in Table I. The phosphorylation data after 6- and 24-h incubations at high glucose are shown in Fig. 3. Hexokinase $V_{\max }$ and $K_{\mathrm{m}}$ were unaffected by the high glucose. In contrast, glucokinase $V_{\max }$ was increased at all time points: $149 \pm 4 \%$ of control at $6 \mathrm{~h}(P<0.018)$, $161 \pm 10 \%$ of control at $14 \mathrm{~h}(P<0.003)$, and $168 \pm 16 \%$ of control at $24 \mathrm{~h}(P<0.027)$. These values are not different from each other statistically. The $K_{\mathrm{m}}$ for glucokinase was unchanged at any time point.

Glucokinase Western blot. To investigate the etiology of the increased glucokinase $V_{\max }$, a time course of glucokinase protein level was constructed by Western blotting of islets cultured for $6,14,24$, and $48 \mathrm{~h}$ at $16.7 \mathrm{mM}$ glucose. After $6 \mathrm{~h}$ at high glucose, the level of glucokinase was unchanged from the control islets. In contrast, at 14,24 , and $48 \mathrm{~h}$, glucokinase protein levels were increased $\sim 40 \%$. Finding divergent protein levels between $6 \mathrm{~h}$ and the later time points was surprising because the $V_{\max }$ measurements were equal up through $24 \mathrm{~h}$. We retested the observation with additional groups of islets $(n=5)$ studied after 6 and $24 \mathrm{~h}$ of $16.7 \mathrm{mM}$ glucose, and we obtained the same result (Fig. 4). Combined densitometry readings from the five experiments are shown in Fig. 5. Glucokinase protein levels were $101 \pm 8 \%$ of control after $6 \mathrm{~h}$ of high glucose vs $144 \pm 3 \%$ of control with the 24-h incubation $(P<0.0002)$.

Reversal of the high glucose-induced increase in glucokinase activity. We next tested the reversibility of the increased activity of glucokinase after 6 and $24 \mathrm{~h}$ of high glucose by incubating for another $3 \mathrm{~h}$ at $5.5 \mathrm{mM}$ glucose (Table I). Glucokinase $V_{\max }$ decreased to basal control levels in the 6-h high glucose islets ( $112 \pm 8 \%$ of control, $P=\mathrm{NS}$ ), as opposed to no change in the 24-h group ( $141 \pm 7 \%$ of control).

Prevention of the high glucose-induced increase in glucokinase activity by cycloheximide. A third difference between the 6- and 24-h time points pertained to the ability of cycloheximide, an inhibitor of protein synthesis, to prevent the increase in glucokinase activity. Islets were cultured for 6 and $24 \mathrm{~h}$ at 
Table I. Kinetic Parameters for Glucokinase and Hexokinase in Cultured Islets

\begin{tabular}{|c|c|c|c|c|c|c|}
\hline \multirow[b]{2}{*}{ Culture conditions } & \multirow[b]{2}{*}{ Islet DNA } & \multicolumn{2}{|c|}{ Hexokinase } & \multicolumn{3}{|c|}{ Glucokinase } \\
\hline & & $V_{\max }$ & $K_{\mathrm{m}}$ & $V_{\max }$ & $V_{\max }$ & $K_{\mathrm{m}}$ \\
\hline & ng/islet & $\begin{array}{l}\text { mol G-6-P/kg } \\
\text { DNA/60 min }\end{array}$ & mM glucose & $\begin{array}{l}\text { mol G-6-P/kg } \\
\text { DNA/60 min }\end{array}$ & $\begin{array}{c}\text { percent of } \\
\text { matched control }\end{array}$ & $m M$ glucose \\
\hline \multicolumn{7}{|l|}{ Protocol a: $24 \mathrm{~h}$ Total culture } \\
\hline $5.5 \mathrm{mM}$ glucose (3) & $19.3 \pm 1.9$ & $1.32 \pm 0.13$ & $0.09 \pm 0.13$ & $3.59 \pm 0.44$ & $100 \pm 12$ & $18.3 \pm 1.96$ \\
\hline $6 \mathrm{~h}$ of $16.7 \mathrm{mM}$ glucose (3) & $18.8 \pm 3.2$ & $1.49 \pm 0.31$ & $0.08 \pm 0.03$ & $5.37 \pm 0.15^{*}$ & $149 \pm 4^{*}$ & $14.4 \pm 1.31$ \\
\hline $24 \mathrm{~h}$ of $16.7 \mathrm{mM}$ glucose (3) & $20.1 \pm 3.7$ & $1.33 \pm 0.09$ & $0.10 \pm 0.04$ & $6.03 \pm 0.57^{\ddagger}$ & $168 \pm 16^{\ddagger}$ & $17.3 \pm 2.65$ \\
\hline \multicolumn{7}{|l|}{ Protocol b: $18 \mathrm{~h}$ Total culture } \\
\hline $5.5 \mathrm{mM}$ glucose (4) & $16.4 \pm 1.4$ & $3.22 \pm 0.35$ & $0.03 \pm 0.00$ & $4.29 \pm 0.32$ & $100 \pm 7$ & $11.9 \pm 1.08$ \\
\hline $14 \mathrm{~h}$ at $16.7 \mathrm{mM}$ glucose (4) & $17.8 \pm 1.2$ & $2.54 \pm 0.43$ & $0.02 \pm 0.00$ & $6.92 \pm 0.45^{8}$ & $161 \pm 10^{8}$ & $14.4 \pm 1.03$ \\
\hline \multicolumn{7}{|l|}{ Protocol c: Reversal ${ }^{\top}$} \\
\hline $5.5 \mathrm{mM}$ glucose (3) & $13.6 \pm 1.8$ & $4.47 \pm 0.31$ & $0.02 \pm 0.00$ & $5.04 \pm 0.12$ & $100 \pm 2$ & $16.6 \pm 2.28$ \\
\hline $6 \mathrm{~h}$ of $16.7 \mathrm{mM}$ glucose (3) & $13.8 \pm 1.6$ & $4.70 \pm 0.57$ & $0.03 \pm 0.01$ & $5.65 \pm 0.42$ & $112 \pm 8$ & $14.4 \pm 2.40$ \\
\hline $24 \mathrm{~h}$ of $16.7 \mathrm{mM}$ glucose (3) & $15.3 \pm 2.9$ & $3.90 \pm 0.28$ & $0.02 \pm 0.00$ & $7.09 \pm 0.34^{\|}$ & $141 \pm 7^{\|}$ & $12.1 \pm 2.09$ \\
\hline
\end{tabular}

Statistical significance was determined by comparing each group of islets cultured at $16.7 \mathrm{mM}$ glucose against the time-matched group at $5.5 \mathrm{mM}$ glucose. ${ }^{*} P<0.018,{ }^{\ddagger} P<0.027,{ }^{\&} P<0.003, \| P<0.0046 . V_{\max }$ and $K_{\mathrm{m}}$ values for hexokinase and glucokinase were caculated as described in the text. The reversal protocol entailed the culture conditions shown followed by an additional $3 \mathrm{~h}$ at $5.5 \mathrm{mM}$ glucose.

$16.7 \mathrm{mM}$ glucose in the presence or absence of $10 \mu \mathrm{M}$ cycloheximide. The previous findings concerning the glucokinase $V_{\max }$ and protein levels after 6 and $24 \mathrm{~h}$ of high glucose were replicated in the islets not exposed to cycloheximide (Table II). Cycloheximide did not prevent the increase in glucokinase $V_{\max }$ that occurred with the 6-h incubation at high glucose (Fig. 6); the $V_{\max }$ was similar with (144 $\pm 14 \%$ of control) and without (136 $\pm 4 \%$ of control) cycloheximide. In contrast, with $24 \mathrm{~h}$ of high glucose, cycloheximide halved the increase in glucokinase $V_{\max }(126 \pm 8 \%$ of control with cycloheximide and $158 \pm 7 \%$ of control without cycloheximide, $P<0.027)$. However, the $V_{\max }$ was still significantly increased $(P<0.035$ vs $5.5 \mathrm{mM}$ glucose islets), even though the rise in the glucokinase protein level

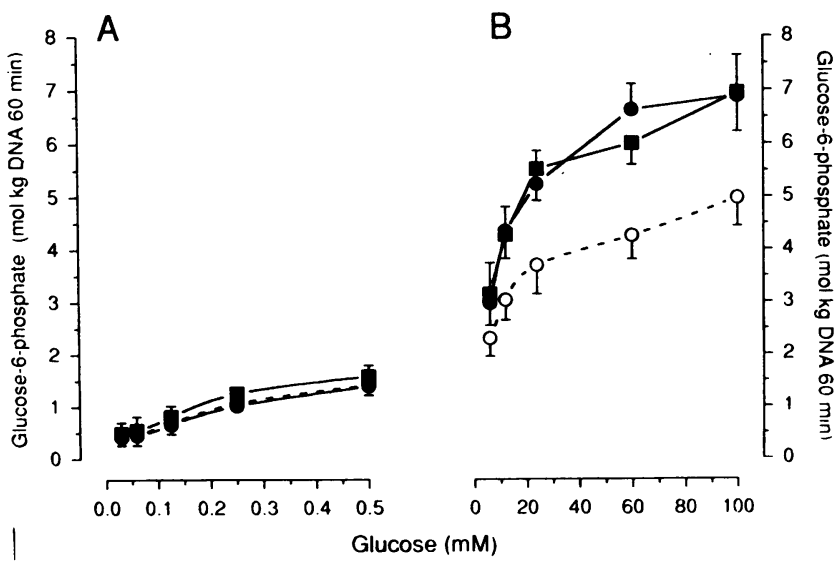

Figure 3. Glucose phosphorylation to glucose-6-phosphate in rat islets during 90-min incubations at the glucose concentrations shown. Islets were cultured $6 \mathrm{~h}$ at $16.7 \mathrm{mM}$ glucose preceded by $18 \mathrm{~h}$ at $5.5 \mathrm{mM}$ glucose $(\bullet-\cdots n=3), 24 \mathrm{~h}$ at $16.7 \mathrm{mM}$ glucose $(\square-\square=3)$, or $24 \mathrm{~h}$ at $5.5 \mathrm{mM}$ glucose $(O-\longrightarrow \cap n=3)$. (A) Incubations carried out at 0.03-0.5 mM glucose representing hexokinase activity. $(B)$ Incubations carried out at 6-100 mM glucose representing glucokinase activity. had been totally blocked (102 $\pm 10 \%$ of control) (Fig. 7). These data support the notion of dual regulatory effects of glucose to control the synthesis and catalytic activity of glucokinase. Protein synthesis is not required for the second effect.

\section{Discussion}

By mapping out a 24-h profile of glucokinase activity and protein levels plus the $\mathrm{ED}_{50}$ for glucose-induced insulin secretion in islets cultured at a high concentration of glucose, new insight was obtained into how $\beta$ cells adapt to hyperglycemia. Two modes of regulation for glucokinase were noted, with relatively acute changes in the catalytic activity followed by a more chronic increase in the cellular content of the enzyme. Furthermore, the setpoint for insulin secretion was lowered in concert with the upregulated glucokinase activity, which fits with the well-known role of this enzyme in regulating the $\beta$ cell sensitivity to glucose (2). Thus, our results revealed for the first time a multistep sequence of $\beta$ cell adaptive responses that are initi-

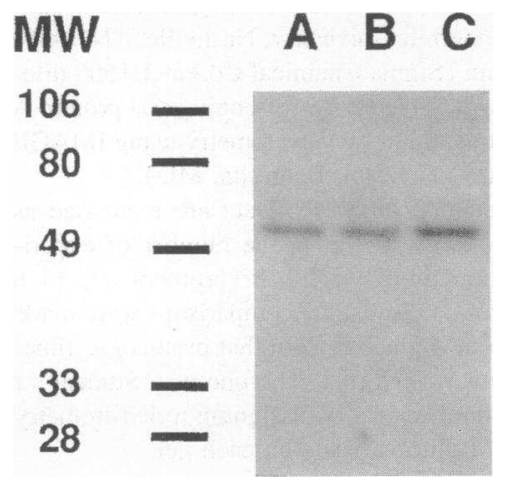

Figure 4. Western blot for glucokinase in cultured rat islets. Culture conditions: $6 \mathrm{~h}$ at 16.7 $\mathrm{mM}$ glucose preceded by $18 \mathrm{~h}$ at $5.5 \mathrm{mM}$ glucose $(A), 24 \mathrm{~h}$ at $5.5 \mathrm{mM}$ glucose $(B), 24 \mathrm{~h}$ at 16.7 $\mathrm{mM}(C)$. Protein aliquots $(20 \mu \mathrm{g})$ were resolved by electrophoresis on a polyacrylamide gel and transferred onto nitrocellulose. Filters underwent sequential incu-

bations with a polyclonal sheep antiserum raised against an $E$. coliderived B1 isoform of rat glucokinase, then rabbit anti-sheep IgG. Bound antibody was detected with ${ }^{125} \mathrm{I}$-conjugated protein $\mathrm{A}$. 


\begin{tabular}{|c|c|c|c|c|c|c|}
\hline \multirow[b]{2}{*}{ Culture conditions } & \multicolumn{2}{|c|}{ Hexokinase } & \multicolumn{4}{|c|}{ Glucokinase } \\
\hline & $V_{\max }$ & $K_{\mathrm{m}}$ & $V_{\max }$ & $V_{\max }$ & $K_{\mathrm{m}}$ & $\begin{array}{c}\text { Protein on } \\
\text { Western blot }\end{array}$ \\
\hline & $\begin{array}{c}\text { mol G-6-P/kg } \\
D N A / 60 \mathrm{~min}\end{array}$ & mM glucose & $\begin{array}{c}\text { mol G-6-P/kg } \\
D N A / 60 \mathrm{~min}\end{array}$ & $\begin{array}{c}\text { percent of } \\
\text { matched control }\end{array}$ & mM glucose & $\%$ control \\
\hline \multicolumn{7}{|l|}{ Protocol d: cycloheximide } \\
\hline 5.5 mM Glucose (3) & $4.98 \pm 1.50$ & $0.12 \pm 0.03$ & $4.87 \pm 0.15$ & $100 \pm 3$ & $12.4 \pm 1.4$ & 100 \\
\hline $6 \mathrm{~h}$ of $16.7 \mathrm{mM}(3)$ & $4.91 \pm 1.27$ & $0.12 \pm 0.03$ & $6.66 \pm 0.18^{*}$ & $136 \pm 4^{*}$ & $14.8 \pm 0.9$ & $100 \pm 3$ \\
\hline \multicolumn{7}{|l|}{$6 \mathrm{~h}$ of $16.7 \mathrm{mM}$} \\
\hline$+10 \mu \mathrm{M}$ Cycloheximide (3) & $4.50 \pm 1.41$ & $0.13 \pm 0.05$ & $7.01 \pm 0.66^{\ddagger}$ & $144 \pm 14^{\ddagger}$ & $17.4 \pm 2.2$ & $100 \pm 4$ \\
\hline $5.5 \mathrm{mM}$ Glucose (4) & $4.71 \pm 0.31$ & $0.10 \pm 0.02$ & $5.42 \pm 0.26$ & $100 \pm 5$ & $15.5 \pm 5.6$ & 100 \\
\hline $24 \mathrm{~h}$ of $16.7 \mathrm{mM}(4)$ & $4.81 \pm 0.46$ & $0.11 \pm 0.5$ & $8.54 \pm 0.40^{8}$ & $158 \pm 7^{\S}$ & $12.5 \pm 2.4$ & $141 \pm 9^{9}$ \\
\hline \multicolumn{7}{|l|}{$24 \mathrm{~h}$ of $16.7 \mathrm{mM}$} \\
\hline$+10 \mu \mathrm{M}$ Cycloheximide (4) & $3.86 \pm 0.76$ & $0.11 \pm 0.04$ & $6.82 \pm 0.45^{\|}$ & $126 \pm 7^{\| \prime}$ & $11.1 \pm 2.4$ & $102 \pm 10$ \\
\hline
\end{tabular}

Statistical significance was determined by comparing each group of islets cultured at $16.7 \mathrm{mM}$ glucose against the time-matched group at $5.5 \mathrm{mM}$ glucose. $* P<0.002, \quad{ }^{\ddagger} P<0.001, \quad \| P<0.035, \quad{ }^{\prime} P<0.02$.

ated by a high level of glucose. Almost immediately, insulin levels rise because of the direct stimulation of insulin secretion. If that degree of insulin release does not normalize the glucose concentration, a few hours later, the inductive effect on glucokinase catalytic activity causes a further increase in insulin output because of the increased $\beta$ cell sensitivity to glucose. With persistent hyperglycemia, a third effect to augment the cellular content of glucokinase is added.

Glucose modulating the cellular content of glucokinase is a well-known regulatory mechanism for this enzyme $(7,8)$. In contrast, control of the catalytic activity of glucokinase separate from changes in the amount of enzyme is a new concept that is still controversial. Iynedjian et al. (18) proposed this possibility to explain the reduced glucokinase activity that occurs in islets from rats fasted for $72 \mathrm{~h}(19)$. We expanded the idea to insulin-resistant states by finding increased enzymatic activity of glucokinase without changes in the level of the protein measured by Western blotting in islets isolated from two hyperinsulinemic rat models $(8,9)$. The present study provided irrefutable evidence for the catalytic activity being a locus of regulation for this enzyme. The results with cycloheximide in the 6-

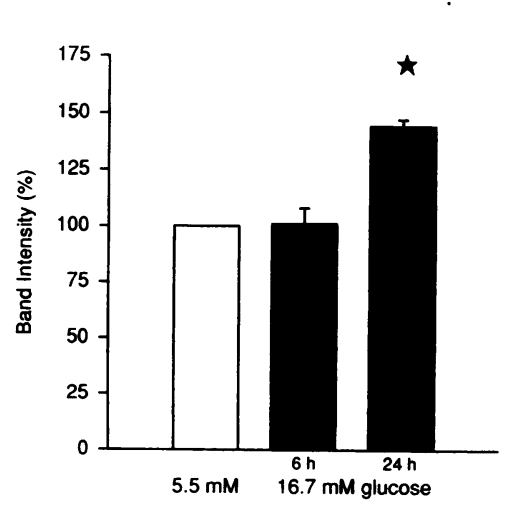

Figure 5. Combined data from five experiments for glucokinase protein level in cultured rat islets. Culture conditions: $24 \mathrm{~h}$ at $5.5 \mathrm{mM}$ glucose, $6 \mathrm{~h}$ at $16.7 \mathrm{mM}$ glucose preceded by $18 \mathrm{~h}$ at $5.5 \mathrm{mM}$ glucose, and $24 \mathrm{~h}$ at 16.7 $\mathrm{mM}$ glucose. Glucokinase was quantified by Western blot. The glucokinase bands on each gel were measured by

densitometry and expressed in relative terms against the islets cultured at $5.5 \mathrm{mM}$ glucose (designated as $100 \%$ ). $\star P<0.0002$ vs the 5.5 $\mathrm{mM}$ glucose islets. $\mathrm{h}$ high glucose islets were the most telling. The concentration used $(10 \mu \mathrm{M})$ is known to abolish islet protein synthesis (20). Still, the $V_{\max }$ increased as with high glucose alone, which can only indicate an increase in the ratio of enzyme activity to protein level. The stimulus for the increased glucokinase activity in this study was a high level of glucose. Our previous studies made similar findings in normoglycemic rats: normoglycemic/ hyperinsulinemic rats from a 48-h glucose infusion (8), and in spontaneously hypertensive rats (9), a model of insulin resistance with normal glucose tolerance $(21,22)$. It remains to be determined whether multiple regulatory factors for glucokinase catalytic activity exist, one of which is glucose.

Therefore, adaptive changes of the catalytic activity of glucokinase have now been reported in such diverse situations as fasting and refeeding (18), insulin resistance (9), and this study with high glucose. Knowing the central role played by glucokinase in determining the $\beta$ cell sensitivity for glucose and insulin output (2), these findings strongly suggest that the catalytic
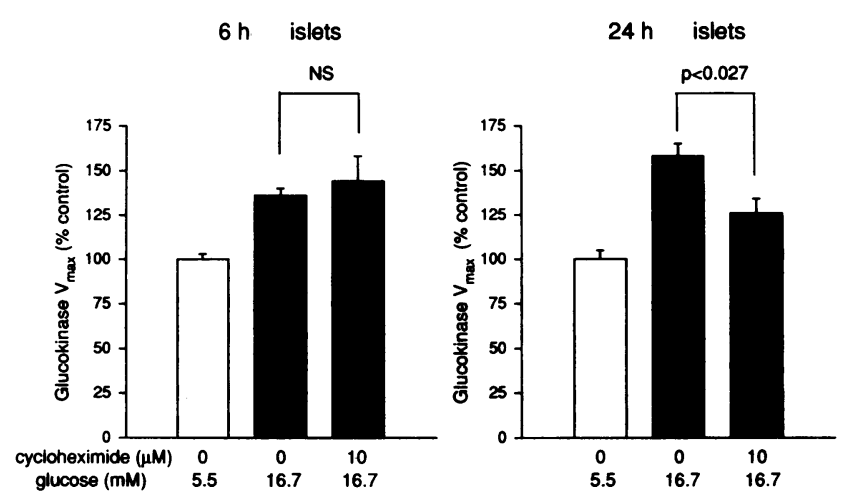

Figure 6. Effect of cycloheximide to prevent the high glucose-induced increase in glucokinase $V_{\max }$. Islets were cultured for $6 \mathrm{~h}(n=3)$ or $24 \mathrm{~h}(n=4)$ at $16.7 \mathrm{mM}$ glucose in the presence or absence of $10 \mu \mathrm{M}$ cycloheximide. Glucokinase $V_{\max }$ was measured as described in the text, and it was expressed as percentage of control islets (cultured at $5.5 \mathrm{mM}$ glucose) 


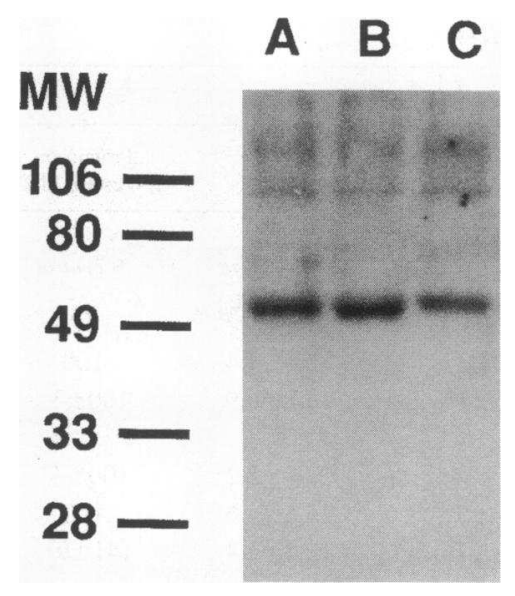

Figure 7. Western blot for glucokinase in rat islets cultured in the presence of cycloheximide. Culture conditions: $24 \mathrm{~h}$ at $5.5 \mathrm{mM}$ glucose $(A)$, $24 \mathrm{~h}$ at $16.7 \mathrm{mM}$ glucose $(B)$, and $24 \mathrm{~h}$ at 16.7 $\mathrm{mM}$ glucose $+10 \mu \mathrm{M}$ cycloheximide $(C)$.

activity of glucokinase is a key locus of regulation in the $\beta$ cell for mediating adaptive changes in insulin output. Potential mechanisms include the inhibitory protein for glucokinase that has been identified in the liver $(23,24)$. However, our results virtually eliminated this possibility because that protein is a competitive inhibitor of glucokinase that alters the affinity $\left(E D_{50}\right)$ for glucose, not the $V_{\max }(24)$. An area of current speculation concerns a regulatory role for the $\beta$ cell glucose transporter GLUT-2 on glucokinase (25-27). Consistent with this idea, we observed that GLUT-2 levels were increased in tandem with an increased activity of glucokinase in islets isolated from spontaneously hypertensive rats (9). Nonetheless, the current results seem incompatible with the level of GLUT-2 being the regulatory factor because the increase in glucokinase activity with $6 \mathrm{~h}$ of high glucose was unaffected by the presence of the protein synthesis inhibitor cycloheximide. An alternate possibility not addressed in this study is a regulatory role for GLUT-2 based on the flux of glucose uptake through the transporter.

In summary, we have confirmed the presence of a dual regulatory system for glucokinase in the $\beta$ cell, with glucosemediated control of the activity and cellular content of this enzyme. These results markedly strengthen the growing literature that suggests that the catalytic activity of glucokinase is a key site of $\beta$ cell regulatory control, which, until recently, has gone unrecognized.

\section{Acknowledgments}

This work was supported by National Institutes of Health grant DK36836 and by a research grant from the Juvenile Diabetes Foundation. Dr. Chen is supported by a postdoctoral fellowship from the Juvenile Diabetes Foundation.

\section{References}

1. Matschinsky, F. M. 1990. Glucokinase as glucose sensor and metabolic generator in pancreatic $\beta$ cells and hepatocytes. Diabetes. 39:647-652.

2. Matschinsky, F., Y. Liang, P. Kesavan, L. Wang, P. Froguel, G. Velho, D. Cohen, M. A. Permutt, Y. Tanizawa, T. L. Jetton, K. Niswender, and M. A. Magnuson. 1993. Glucokinase as $\beta$ cell glucose sensor and diabetes gene. J. Clin. Invest. 92:2092-2098.

3. Froguel, P., H. Zouali, N. Vionnet, G. Velho, M. Vaxillaire, F. Sun, S. Lesage, M. Stouffel, J. Takeda, P. Passa, M. A. Permutt, J. S. Beckmann, G. I. Bell, and D. Cohen. 1993. Familial hyperglycemia due to mutations in glucokinase. Definition of a subtype of diabetes mellitus. N. Engl. J. Med. 328:697-702.
4. Permutt, M. A., K. C. Chiu, and Y. Tanizawa. 1992. Glucokinase and NIDDM. A candidate gene that paid off. Diabetes. 41:1367-1372.

5. Magnuson, M. A. 1992. Tissue-specific regulation of glucokinase gene expression. J. Cell. Biochem. 48:115-121.

6. Iynedjian, P. B. 1993. Mammalian glucokinase and its gene. Biochem. J. 293:1-13.

7. Liang, Y., H. Najafi, R. M. Smith, E. C. Zimmerman, M. A. Magnuson, M. Tal, and F. M. Matschinsky. 1992. Concordant glucose induction of glucokinase, glucose usage, and glucose-stimulated insulin release in pancreatic islets maintained in organ culture. Diabetes. 41:792-806.

8. Chen, C., L. Bumbalo, and J. L. Leahy. 1994. Increased catalytic activity of glucokinase in isolated islets from hyperinsulinemic rats. Diabetes. 43:684689.

9. Chen, C., H. Hosokawa, L. M. Bumbalo, and J. L. Leahy. 1994. Mechanism of compensatory hyperinsulinemia in normoglycemic insulin resistant SHR rats: augmented enzymatic activity of glucokinase in $\beta$-cells. J. Clin. Invest. 94:399404.

10. Gotoh, M., T. Maki, S. Satomi, J. Porter, S. Bonner-Weir, C. J. O'Hara, and A. P. Monaco. 1987. Reproducible high yield of rat islets by stationary in vitro digestion following pancreatic ductal or portal venous collagenase injection. Transplantation (Baltimore). 43:725-730.

11. Albano, J. D. M., R. P. Ekins, G. Maritz, and R. C. Turner. 1972. A sensitive, precise radioimmunoassay of serum insulin relying on charcoal separation of bound and free hormone moieties. Acta Endocrinol. 70:487-509.

12. Meglasson, M. D., and F. M. Matschinsky. 1984. Purification of the putative islet cell glucose sensor glucokinase from isolated pancreatic islets and insulinoma tissue. In Methods in Diabetes Research. Vol. 1. Laboratory Methods, Part A. J. Larner and S. Pohl, editors. John Wiley \& Sons Inc., New York. pp. 213-225

13. Labarca, C., and K. D. Paigen. 1980. A simple, rapid, and sensitive DNA assay procedure. Anal. Biochem. 102:344-352.

14. Liang, Y., H. Najafi, and F. M. Matschinsky. 1990. Glucose regulates glucokinase activity in cultured islets from rat pancreas. J. Biol. Chem. 265:16863-16866.

15. Salas, J., M. Salas, E. Vinuela, and A. Sols. 1965. Glucokinase of rabbit liver: purification and properties. J. Biol. Chem. 240:1014-1018.

16. Spears, G., G. T. Sneyd, and E. G. Loten. 1971. A method for deriving kinetic constants for two enzymes acting on the same substrate. Biochem. J. 125:1149-1151.

17. Iynedjian, P. B., G. Möbius, H. J. Seitz, C. B. Wollheim, and A. E. Renold. 1986. Tissue-specific expression of glucokinase: identification of the gene product in liver and pancreatic islets. Proc. Natl. Acad. Sci. USA. 83:1998-2001.

18. Iynedjian, P. B., P.-R. Pilot, T. Nouspikel, J. L. Milburn, C. Quaade, S. Hughes, C. Ucla, and C. B. Newgard. 1989. Differential expression and regulation of the glucokinase gene in liver and islets of Langerhans. Proc. Natl. Acad. Sci. USA. 86:7838-7842.

19. Burch, P. T., M. D. Trus, D. K. Berner, A. Leontire, K. C. Zawalich, F. M. Matschinsky. 1981. Adaption of glycolytic enzymes: glucose use and insulin release in rat pancreatic islets during fasting and refeeding. Diabetes. 30:923928.

20. Hughes, J. H., J. R. Colca, R. A. Eason, J. Turk, and M. L. McDaniel 1990. Interleukin 1 inhibits insulin secretion from isolated rat pancreatic islets by a process that requires gene transcription and mRNA translation. J. Clin. Invest. 86:856-863.

21. Mondon, C. E., and G. M. Reaven. 1988. Evidence of abnormalities of insulin metabolism in rats with spontaneous hypertension. Metabolism. 37:303305 .

22. Buchanan, T. A., J. H. Youn, V. M. Campese, and G. F. Sipos. 1992 Enhanced glucose tolerance in spontaneously hypertensive rats. Pancreatic $\beta$-cell hyperfunction with normal insulin sensitivity. Diabetes. 41:872-878.

23. Malaisse, W. J., F. Malaisse-Lagae, D. R. Davies, A. Vandercammen, and E. Van Schaftingen. 1990. Regulation of glucokinase by a fructose-1-phosphatesensitive protein in pancreatic islets. Eur. J. Biochem. 190:539-545.

24. Van Schaftingen, E., A. Vandercammen, M. Detheux, and D. R. Davies. 1992. The regulatory protein of liver glucokinase. Adv. Enzyme Regul. 32:133148.

25. Hughes, S. D., C. Quaade, J. H. Johnson, S. Ferber, and C. B. Newgard. 1993. Transfection of AtT-20 $0_{\text {ins }}$ cells with GLUT-2 but not GLUT-1 confers glucose-stimulated insulin secretion. J. Biol. Chem. 268:15205-15212.

26. Purrello, F., M. Buscema, A. M. Rabuazzo, V. Caltabiano, F. Forte, C. Vinci, M. Vetri, and R. Vigneri. 1993. Glucose modulates glucose transporter affinity, glucokinase activity, and secretory response in rat pancreatic beta-cells. Diabetes. 42:199-205.

27. Lachaal, M., and C. Y. Jung. 1993. Interaction of facilitative glucose transporter with glucokinase and its modulation by ADP and glucose-6-phosphate. J. Cell. Physiol. 156:326-332. 